\title{
Potential of Hydrogen Production Through Alkaline Water Electrolysis Using Solar Radiation Around Semarang
}

\author{
Ruth Pranindia Widarningtyas ${ }^{1, *}$, Sulistyo ${ }^{1,2}$, and Widayat ${ }^{1,2}$ \\ ${ }^{1}$ Magister Program of Energy, School of Postgraduate Studies, Diponegoro University, Semarang - Indonesia \\ ${ }^{2}$ Department of Mechanical Engineering, Faculty of Engineering, Diponegoro University, Semarang - Indonesia \\ ${ }^{2}$ Department of Chemical Engineering, Faculty of Engineering, Diponegoro University, Semarang - Indonesia
}

\begin{abstract}
Indonesian society's dependence on fossil fuel and the minimum GHG emission reduction target of $11 \%$ for the energy sector, encourages the development of hydrogen as an eco-friendly renewable energy resource for transportation and industries sector. Electrolysis is one of technology for hydrogen production. Electrolysis technology that utilizes the sun as a generating source is a eco-friendly technology of hydrogen production. The solar intensity in Semarang is $5.49 \mathrm{kWh} / \mathrm{m} 2 /$ day so that is potensial to used for hydrogen production. Solar intensity measurements were carried out in 2 locations in Semarang that have different altitude using single and parallel monocrystalline solar modules with observation from $8 \mathrm{am}-4 \mathrm{pm}$. The measurement results are used as data for calculated the flow rate and the volume of hydrogen that can be produced. The highest hydrogen volume can be produced in Marina for single and parallel panel are 2,099.93 $\mathrm{ml} / \mathrm{h}$ and $4,199.86 \mathrm{ml} / \mathrm{h}$ that are both at $10 \mathrm{am}$. The highest hydrogen volume can be produced in Tembalang for single and parallel panel are $2,693.39 \mathrm{ml} / \mathrm{h}$ at $1 \mathrm{pm}$ and $5,751.98 \mathrm{ml} / \mathrm{h}$ at $11 \mathrm{am}$. The altitude level of location greatly influences the solar intensity for hydrogen production. Parallel panel can produce hydrogen approximately 2 times single panel.
\end{abstract}

Keywords: hydrogen production ; alkaline water electrolysis ; electrochemical ; solar intensity

\section{Introduction}

Fossil fuels whose waste products are one of the contributors to $\mathrm{CO}_{2}$ emissions are still the mainstay of the Indonesian people in meeting energy needs, especially in the industrial sector and transportation. The depletion of fossil fuel reserves and Indonesia's Commitment through the INDC (Nationally Determined Contribution Instrument) in November 2016 to reduce ghg emissions especially the energy sector of $11 \%$ by 2030 [1] it is encourage to get the renewable energy eco-friendly such as hydrogen fuel. Hydrogen is a fuel that has a higher combustion value (Higher Heat Value) which is 141.86 $\mathrm{kJ} / \mathrm{g}$ compared to gasoline which is only $47.5 \mathrm{~kJ} / \mathrm{g}\left(25^{\circ} \mathrm{C}\right.$ and $1 \mathrm{~atm}$ ) and other solid fuels only $50 \mathrm{~kJ} / \mathrm{g}$ [2] and the rest of waste hydrogen production is just water [3] and heat. Hydrogen is found in nature, not in the free elements, so it needed other processes. They include the extraction of natural gas $(48 \%)$, oil industry, $(18 \%)$, coal gasification $(30 \%)$, electrolysis process $(3.9 \%)$ and other processes $(0.1 \%)$ [4]. The electrolysis process is one of the technological processes to produce hydrogen gas that is eco-friendly compared to other processes but has the disadvantage of the value of low combustion and more expensive [5]. Electrolysis cells consist of 4 components: anode, cathode, electrolyte and current. The reactions that occur in the formation of hydrogen from water are :

- Basic reaction processes at the anode

$$
2 \mathrm{OH}^{-} \longrightarrow \mathrm{H}_{2} \mathrm{O}+1 / 2 \mathrm{O}_{2}+2 \mathrm{e}^{-}
$$

- Reaction processes at the cathode $2 \mathrm{H}_{2} \mathrm{O}+2 \mathrm{e}^{-} \longrightarrow 2 \mathrm{OH}^{-}+\mathrm{H}_{2}$

- Over all reaction $\mathrm{H}_{2} \mathrm{O} \longrightarrow \mathrm{H}_{2}+1 / 2 \mathrm{O}_{2}$

Electrolysis systems that have developed are alkaline water electrolysis (AWE), proton exchange membranes (PEMs), alkaline anion exchange membranes (AEMs), and solid oxide water electrolysis (SOE).

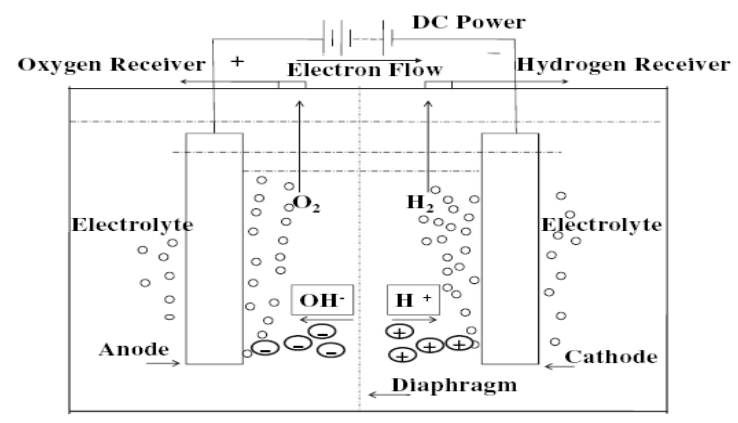

Fig. 1. Electrolysis cell

Figure 1 shows water electrolytic cells [6]. Alkaline water electrolysis has advantages such as electrolytes in the form of solutions such as $\mathrm{NaOH}$ and $\mathrm{KOH}$, low reaction temperature, the maximum operating current density is less than $400 \mathrm{~mA} / \mathrm{cm}^{2}$, and the power

* Corresponding author: ruth.pranindia@gmail.com 
consumption for $\mathrm{H}_{2}$ production is around 4.5-5.5 $\mathrm{kWh} /$ $\mathrm{Nm} 3$ with an efficiency of around 60\% [2].

Electricity is used as an electrolytic cell current source. The electrolysis process can be more efficient if cheap electricity is available [5], such as solar energy. Semarang is one of the cities in Indonesia that has considerable irradiation, with a potential of $5.49 \mathrm{kWh} /$ $\mathrm{m} 2$ / day even in 2017 reaching $8.454 \mathrm{kWh} / \mathrm{m} 2$ / day. This research is to analyze the prediction of the production of hydrogen from the alkaline water electrolysis by utilizing the irradiation in several regions in Semarang which have different altitude. The production of hydrogen is calculated by Faraday's Law and stoichiometric equations of oxidation-reduction reactions based on solar intensity data that have been obtained.

\section{Methodology of study}

\subsection{Flow chart of study}

The flow chart used for this study is shown in Figure 2 below.

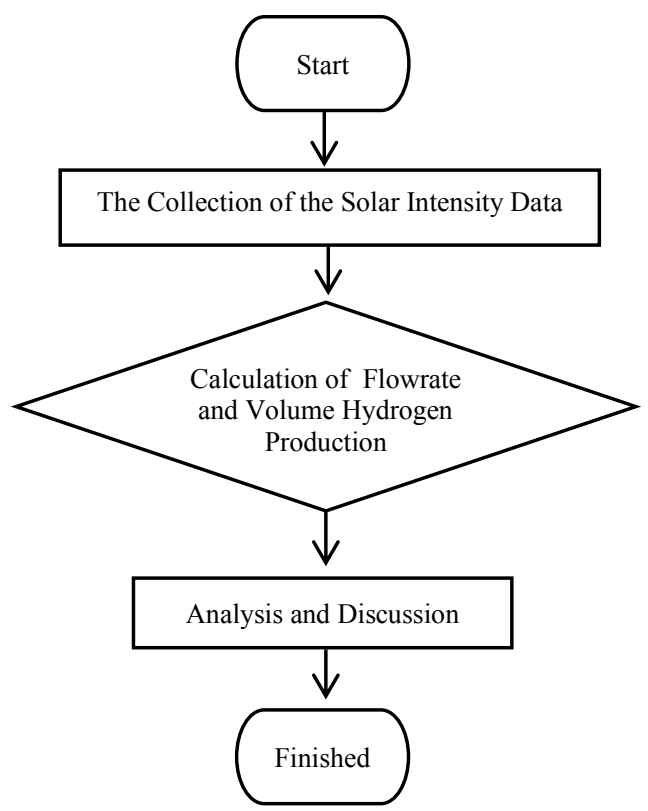

Fig. 2. Flowchart of methods

\subsection{Solar Intensity Data}

Solar intensity data were taken from two locations in Semarang which have varying altitude levels, namely Marina and Tembalang [7]. The solar panels used were monocrystalline, which are single and parallel. Data collection was carried out for nine hours from 8 a.m to 4 p.m.

\subsection{Photovoltaic}

Solar cells are semiconductor elements with the function of converting solar energy into electrical energy on the basis of photovoltaic effects. Sunlight which contains photons then regards electrons will energize electrons, electrons will be released from the atom and move freely. The charge of electrons will pair to form ion-electrodes or electrons in holes in semiconductor materials so that there are potential differences. The transfer of these electrons causes an electric current. Electric current is circulated through external circuits [8]

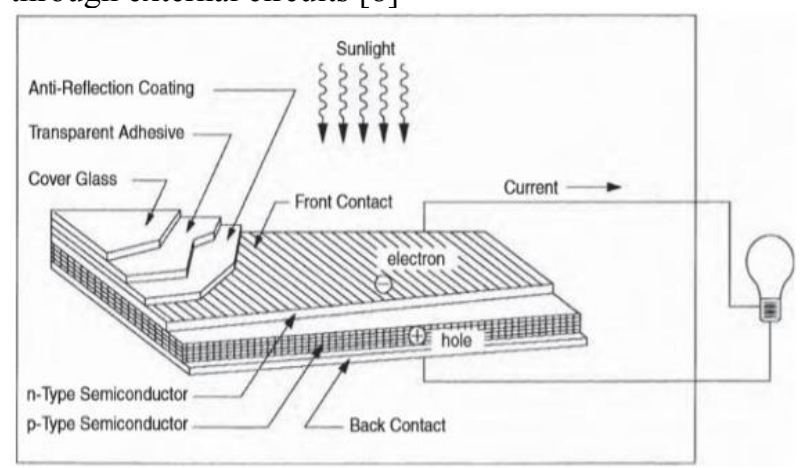

Fig. 3. Photovoltaic cell

The semiconductor element that is widely used today is silicon. The $\mathrm{P}$ semiconductor layer has excess holes, whereas in the semiconductor layer $\mathrm{N}$ has excess electrons. This allows the flow of electrons to cause electric current [9].

\subsection{Solar Panel Installation}

The installation of solar panel is shown in Figure 4. Solar radiation is received by the photovoltaic module. SCR is a Solar charge controller, that functions to regulate the output voltage of a solar panel. So, there is no overcharging when the battery is charging. Batteries are used as energy storage media produced by solar panels. The battery used is VRLA type [7].

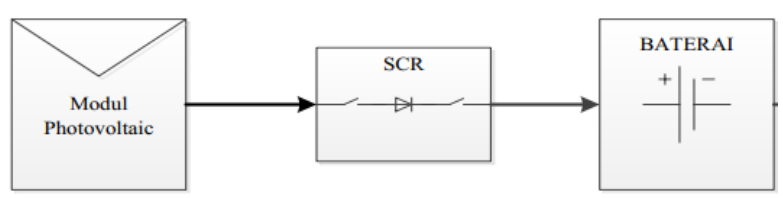

Fig. 4. Solar Panel Installation

\subsection{Solar Radiation Potensial in Semarang}

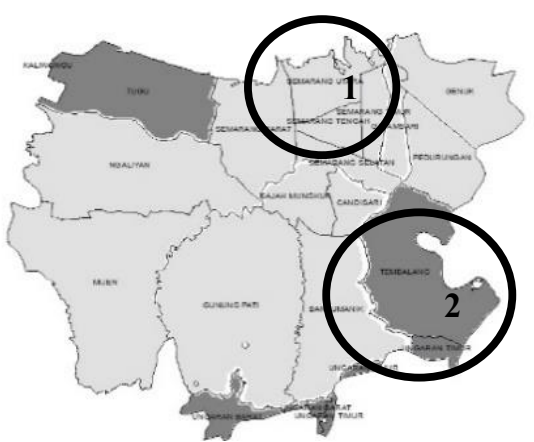

Fig. 5. Semarang Solar Radiation Map

By using arcgis 10, Semarang city is mapped for based on the potential of solar radiation as a source of energy for solar panels at each sub-district that is shown 
in Figure 5. Number 1 shows the location of Marina and number 2 is the location of Tembalang. The darker grey shows large solar radiation and solar radiation with a moderate value indicated by lighter grey.

\subsection{Electrolysis With Photovoltaic Panel}

Figure 6 shows an example of a water alkaline electrolysis cell using solar radiation received by solar panels as an energy source.[3]. The electrolyte solution in this cell uses a $\mathrm{NaOH}$ alkaline solution. Solar panels are connected by electrolysis cells using cables, consisting of voltmeters, ammeters and solar radiation meters. Hydrogen gas as the main product and oxygen as a by-product, is captured using a gasometric ampule equipped with a flow meter to monitor the flow rate of hydrogen and oxygen gas. Gas in gasometric ampules is analyzed using gas chromatography.

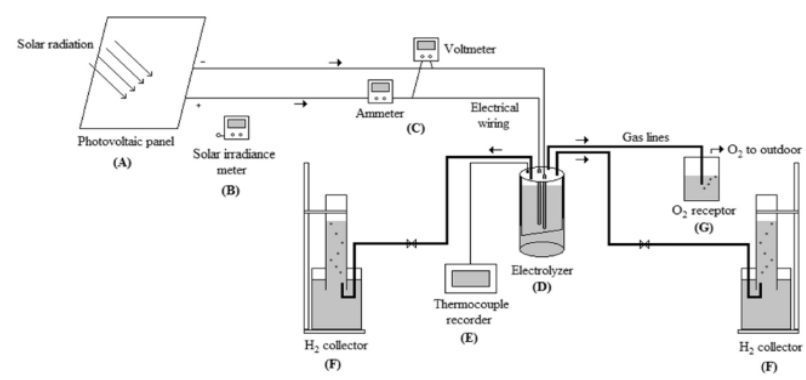

Fig. 6. Electrolysis With Photovoltaic Panel

\subsection{Basic Equation of Gibbs Free Energy, Electrical Work and Voltage}

Gibbs energy can be considered as the clean energy that needed to create a system. The Gibbs energy of hydrogen gas formation is $-237.13 \mathrm{Kj} / \mathrm{mol}$ [10].

Anode $: 2 \mathrm{OH}^{-} \rightarrow \mathrm{H}_{2} \mathrm{O}+1 / 2 \mathrm{O}_{2}+2 \mathrm{e}^{-}$

Cathode: $2 \mathrm{H}_{2} \mathrm{O}+2 \mathrm{e}^{-} \rightarrow 2 \mathrm{OH}^{-}+\mathrm{H}_{2}$

Over all $: \mathrm{H}_{2} \mathrm{O} \rightarrow \mathrm{H}_{2}+1 / 2 \mathrm{O}_{2}$

$$
\Delta \mathrm{G}=\Delta \mathrm{G} \text { product } \Delta \mathrm{G} \text { reactan }
$$

The relationship between Gibbs Free Energy and Electrical Works is in a stable condition at a constant pressure and temperature as follows:

$$
\begin{gathered}
\mathrm{dG}=\mathrm{dU}-\mathrm{T} \mathrm{dS}-\mathrm{SdT}+\mathrm{pdV}+\mathrm{Vdp} \\
\mathrm{dU}=\mathrm{T} \mathrm{dS}+\mathrm{dW}=\mathrm{T} \mathrm{dS}-(\mathrm{pdV}-\mathrm{dWelec}) \\
\mathrm{dG}=-\mathrm{SdT}+\mathrm{V} \mathrm{dp}+\mathrm{dWelec} \\
\mathrm{dG}=\mathrm{dWelec}
\end{gathered}
$$

With Welec $=\mathrm{EQ}$ and $\mathrm{Q}=\mathrm{nF}$, the relation between energy gibbs and voltage is written as the following equation [11] :

$$
\Delta \hat{g}=n F E
$$

\subsection{Hydrogen Ideal Volume}

The hydrogen flow rate at equilibrium is written in the equation :

$$
\mathrm{V}_{\mathrm{H}_{2}}=\frac{\mathrm{i}}{\mathrm{nF}}
$$

Using Faraday's law, and assuming that hydrogen is an ideal gas, the volume of hydrogen can be written with the equation [12] :

$$
\mathrm{V}_{\mathrm{H}_{2}} \text { ideal }=\frac{\mathrm{I} \times \mathrm{V}_{\mathrm{M}} \times \mathrm{t}}{2 \times \mathrm{F}}
$$

$\mathrm{V}_{\mathrm{M}}$ is the molar volume of ideal gas under standard conditions (298.15 K and $1 \mathrm{~atm})$ and F is Faraday's number (96 $485 \mathrm{C} / \mathrm{mol})$. Hydrogen gas volume in STP conditions (298.15 K and $1 \mathrm{~atm})$ is $24.47 \mathrm{l} / \mathrm{mol}$ [13].

\section{Results and discussion}

\begin{tabular}{|c|c|c|c|}
\hline \multirow[b]{2}{*}{ Time } & \multicolumn{3}{|c|}{ Marina } \\
\hline & $\begin{array}{l}\text { Curren } \\
\mathrm{t}(\mathrm{A})\end{array}$ & $\begin{array}{c}\text { Flowrate of } \\
\text { Hydrogen }(\mathrm{mol} / \mathrm{h})\end{array}$ & $\begin{array}{c}\text { Hydrogen } \\
\text { Volume }(\mathrm{ml} / \mathrm{h}) \\
\end{array}$ \\
\hline 8 a.m & 2.3 & 0.043 & $1,049.96$ \\
\hline 9 a.m & 3 & 0.056 & $1,369.52$ \\
\hline 10 a.m & 4.6 & 0.086 & $2,099.93$ \\
\hline 11 a.m & 4.2 & 0.078 & $1,917.33$ \\
\hline 12 p.m & 4.4 & 0.082 & $2,008.63$ \\
\hline 1 p.m & 3.7 & 0.069 & $1,689.07$ \\
\hline 2 p.m & 2.8 & 0.052 & $1,278.22$ \\
\hline 3 p.m & 2.2 & 0.041 & $1,004.31$ \\
\hline 4 p.m & 1.3 & 0.024 & 593.46 \\
\hline \multirow[b]{2}{*}{ Time } & \multicolumn{3}{|c|}{ Tembalang } \\
\hline & $\begin{array}{l}\text { Curren } \\
\mathrm{t}(\mathrm{A})\end{array}$ & $\begin{array}{c}\text { Flowrate of } \\
\text { Hydrogen }(\mathrm{mol} / \mathrm{h})\end{array}$ & $\begin{array}{c}\text { Hydrogen } \\
\text { Volume }(\mathrm{ml} / \mathrm{h}) \\
\end{array}$ \\
\hline 8 a.m & 3.3 & 0.062 & $1,506.47$ \\
\hline 9 a.m & 5 & 0.093 & $2,282.53$ \\
\hline 10 a.m & 5.9 & 0.110 & $2,693.39$ \\
\hline 11 a.m & 5.8 & 0.108 & $2,647.74$ \\
\hline 12 p.m & 5.8 & 0.108 & $2,647.74$ \\
\hline 1 p.m & 5.9 & 0.110 & $2,693.39$ \\
\hline 2 p.m & 5.3 & 0.099 & $2,419.48$ \\
\hline 3 p.m & 3.9 & 0.073 & $1,780.37$ \\
\hline 4 p.m & 3 & 0.056 & $1,369.52$ \\
\hline
\end{tabular}

\subsection{Solar Intensity Data (Single Panel)}

Table 1 shows current data on batteries for single solar panels that were taken at 2 locations in Semarang, namely Marina and Tembalang. [7].

Table 1. Single Panel Solar Intensity Data

\begin{tabular}{|c|c|c|}
\hline \multirow{2}{*}{ Time } & Marina & Tembalang \\
\cline { 2 - 3 } & \multicolumn{2}{|c|}{ Controller ke Battery } \\
\cline { 2 - 3 } & Id (A) & Id (A) \\
\hline 8 a.m & 2.3 & 3.3 \\
\hline 9 a.m & 3 & 5 \\
\hline 10 a.m & 4.6 & 5.9 \\
\hline 11 a.m & 4.2 & 5.8 \\
\hline 12 p.m & 4.4 & 5.8 \\
\hline 1 p.m & 3.7 & 5.9 \\
\hline 2 p.m & 2.8 & 5.3 \\
\hline 3 p.m & 2.2 & 3.9 \\
\hline 4 p.m & 1.3 & 3 \\
\hline
\end{tabular}

Table 2. Calculation of Hydrogen Production

Table 1 shows that the current from Controller to Battery at the Marina has a lower value with a range of 1.3 to $4.6 \mathrm{~A}$ and the Tembalang location has a higher intensity value with a range of 3 to 5.9 A. Marina location 
has an upward trend from 8 am until 10 am and the trend has a downward trend until $4 \mathrm{pm}$. The high current is between $10 \mathrm{am}$ and $12 \mathrm{pm}$ with the highest value at 10 a.m.at 4.6 A. While the current at the Tembalang location has an upward trend from 8 am until $1 \mathrm{pm}$ with the highest intensity between 10 am and $1 \mathrm{pm}$, with a value between $5.8 \mathrm{~A}$ to $5.9 \mathrm{~A}$. The hydrogen gas volume which is calculation based on potential solar intensity at each location for a single panel as shown in table 2. That is result from redox equation for STP conditions (298.15 K and $1 \mathrm{~atm}$ ) [13] and assumed on steady-state process. In table 2, the magnitude of the solar intensity is proportional to flowrate $(\mathrm{mol} / \mathrm{h})$ and volume of hydrogen production $(\mathrm{ml})$. It shows that the hydrogen production followed irradiance during the day [14]. Table 2 shows the results of calculation flow rate and volume of hydrogen can be produced from the single panel photovoltaic electric current output using equation Hydrogen Ideal Volume. Its value plotted in Figrue 7 and Figure 8.

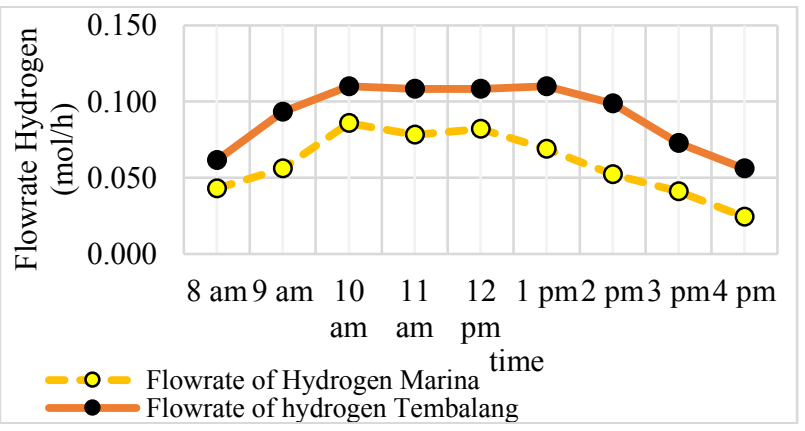

Fig. 7. Curve of Flow Rate Hydrogen for Single Panel PV

The range of hydrogen flow rate that can be produced with the potential radiation intensity at the marina location is 0.024 to $0.086 \mathrm{~mol} /$ hour and the highest at $10 \mathrm{am}$ is $0.086 \mathrm{~mol} /$ hour. Where as the radiation intensity at the Tembalang location can potentially produce hydrogen with a flow rate ranging from 0.062 to $0.11 \mathrm{~mol} /$ hour and the highest value is $0.11 \mathrm{~mol} /$ hour at $1 \mathrm{pm}$.

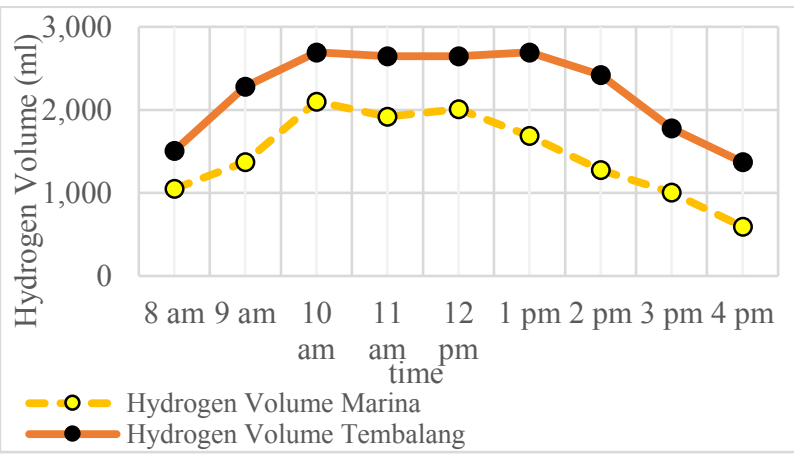

Fig. 8. Curve of Hyrogen Volume for Single Panel PV

Figure 8 shows hydrogen volume can be produced from the availability of solar intensity. For Marina locations, the intensity of the sun can produce hydrogen which has a volume of 593 to $2,100 \mathrm{ml}$ with the highest value is $2,099.93 \mathrm{ml}$ at $10 \mathrm{am}$. Whereas at Tembalang location, the intensity of the sun can produce hydrogen with a volume at 1369 to $2,694 \mathrm{ml}$ the highest amount of hydrogen is produced at 1 p.m. with a value of $2,693.39$ $\mathrm{ml}$.

Figure 9 shows that current be produced of single panel photovoltaic and volume of hydrogen production at each location have comparable values.

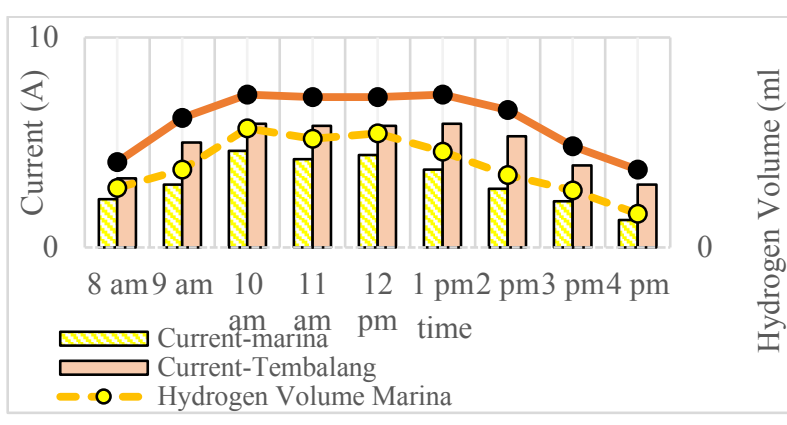

Fig. 9. Curve of Flow Rate Hydrogen and Hydrogen Volume

Marina location has an upward trend from 8 am until $12 \mathrm{pm}$ and then goes down. The solar intensity that is available to be used to produce hydrogen highest volume is at 10 am until $12 \mathrm{pm}$ with a range of hydrogen volume that can be produced is 1,917 to $2,100 \mathrm{ml}$. Whereas in Tembalang location, it has an upward trend from 8 am until $1 \mathrm{pm}$ and then goes down. The value of solar energy that is high enough to be able to produce hydrogen is available from 10 am until $1 \mathrm{pm}$ with volume hydrogen can be produced with a range 2,647 to $2,694 \mathrm{ml}$. The results of this calculation show the amount of hydrogen volume that is produced by the current of photovoltaic module is determined by solar radiation. The total amount of output current by photovoltaic modules is influenced by solar radiation. [15]. The higher current output can increase the volume of hydrogen produced [3].

\subsection{Solar Intensity Data (Parallel Panel)}

Table 3. Parallel Panel Solar Intensity Data

\begin{tabular}{|c|c|c|}
\hline \multirow{2}{*}{ Time } & Marina & Tembalang \\
\cline { 2 - 3 } & \multicolumn{2}{|c|}{ Controller ke Battery } \\
\cline { 2 - 3 } & Id (A) & Id(A) \\
\hline 8 a.m & 6.4 & 6.8 \\
\hline 9 a.m & 7 & 10 \\
\hline 10 a.m & 9.2 & 12.3 \\
\hline 11 a.m & 9 & 12.6 \\
\hline 12 p.m & 8.6 & 10.8 \\
\hline 1 p.m & 7.7 & 8.7 \\
\hline 2 p.m & 6.2 & 5.6 \\
\hline 3 p.m & 3.4 & 4.1 \\
\hline 4 p.m & 1.8 & 3.6 \\
\hline
\end{tabular}

Table 3 shows current form controller to battery of the parallel solar panel which is the solar intensity conversion received by the parallel panel at two locations in Semarang. The current from controller to battery that can be received from parallel photovoltaic panel at the Marina location has an upward trend from 8 am until 10 am and then goes down. The high current is between 10 am until $12 \mathrm{pm}$ with the highest current value at 10 am with value 9.2 A. While in Tembalang the curent value has a starting upward trend from 8am until 11 am with a high current from 10 am until $1 \mathrm{pm}$ and the highest current value at 11 am with value $12.6 \mathrm{~A}$. 
Table 4. Calculation of Hydrogen Production

\begin{tabular}{|c|c|c|c|}
\hline \multirow[b]{2}{*}{ Time } & \multicolumn{3}{|c|}{ Marina } \\
\hline & $\begin{array}{l}\text { Current } \\
\text { (A) }\end{array}$ & $\begin{array}{c}\text { Flowrate of } \\
\text { Hydrogen }(\mathrm{mol} / \mathrm{h}) \\
\end{array}$ & $\begin{array}{c}\text { Hydrogen } \\
\text { Volume }(\mathrm{ml} / \mathrm{h}) \\
\end{array}$ \\
\hline 8 a.m & 6.4 & 0.119 & $2,921.64$ \\
\hline 9 a.m & 7 & 0.131 & $3,195.54$ \\
\hline 10 a.m & 9.2 & 0.172 & $4,199.86$ \\
\hline 11 a.m & 9 & 0.168 & $4,108.56$ \\
\hline 12 p.m & 8.6 & 0.160 & $3,925.95$ \\
\hline 1 p.m & 7.7 & 0.144 & $3,515.10$ \\
\hline 2 p.m & 6.2 & 0.116 & $2,830.34$ \\
\hline 3 p.m & 3.4 & 0.063 & $1,552.12$ \\
\hline 4 p.m & 1.8 & 0.034 & 821.71 \\
\hline \multirow[b]{2}{*}{ Time } & \multicolumn{3}{|c|}{ Tembalang } \\
\hline & $\begin{array}{l}\text { Current } \\
\text { (A) }\end{array}$ & $\begin{array}{c}\text { Flowrate of } \\
\text { Hydrogen }(\mathrm{mol} / \mathrm{h})\end{array}$ & $\begin{array}{c}\text { Hydrogen } \\
\text { Volume }(\mathrm{ml} / \mathrm{h})\end{array}$ \\
\hline 8 a.m & 6.8 & 0.127 & $3,104.24$ \\
\hline 9 a.m & 10 & 0.187 & $4,565.06$ \\
\hline 10 a.m & 12.3 & 0.229 & $5,615.03$ \\
\hline 11 a.m & 12.6 & 0.235 & $5,751.98$ \\
\hline 12 p.m & 10.8 & 0.201 & $4,930.27$ \\
\hline 1 p.m & 8.7 & 0.162 & $3,971.60$ \\
\hline 2 p.m & 5.6 & 0.104 & $2,556.43$ \\
\hline 3 p.m & 4.1 & 0.076 & $1,871.68$ \\
\hline 4 p.m & 3.6 & 0.067 & $1,643.42$ \\
\hline
\end{tabular}

Table 4 is the same as table 2 but it is for electric current output by a parallel panel photovoltaic.

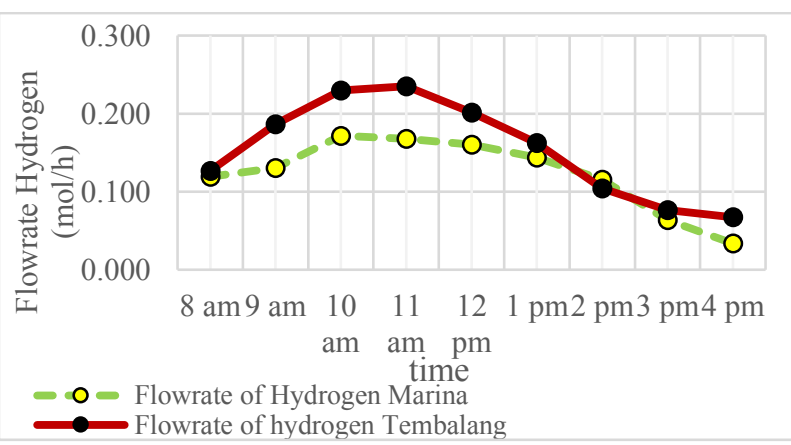

Fig. 10. Curve of Flow Rate Hydrogen for Parallel Panel PV

Figure 10 and Figure 11 show that Marina location receives the solar intensity which potential produced hydrogen with range flowrate and volume is 0.034 to $0.172 \mathrm{~mol} / \mathrm{h}$ and 1,522 to $4,200 \mathrm{ml}$. The highest value at $10 \mathrm{am}$ for hydrogen can be produced is $0.172 \mathrm{~mol} / \mathrm{h}$ for flow rate and 4,199.86 $\mathrm{ml}$ for volume.

While in Tembalang, the range value for flow rate of hydrogen is 0.067 to $0.235 \mathrm{~mol} / \mathrm{h}$ and hydrogen volume can be produced is 1,643 until $5,752 \mathrm{ml}$.

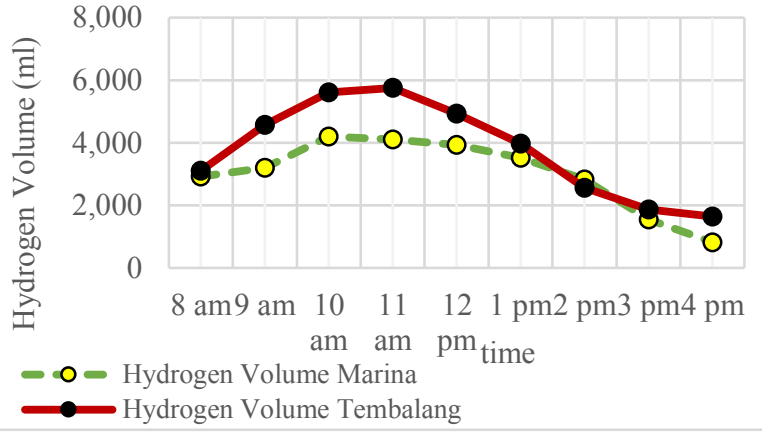

Fig. 11. Curve of Hyrogen Volume for Parallel Panel PV

The highest value for hydrogen that can be produced is at $11 \mathrm{am}$ with value $0.235 \mathrm{~mol} / \mathrm{h}$ and $5,751.98 \mathrm{ml}$ for flow rate and volume.

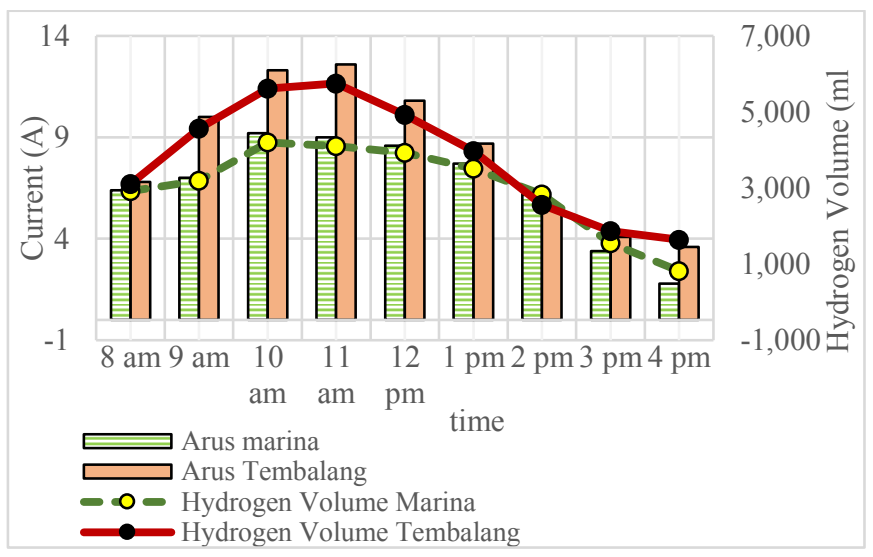

Fig. 12. Curve of Flow Rate Hydrogen and Hydrogen Volume

The comparison of photovoltaic parallel panel output current with the volume hydrogen that can be produced is shown in Figure 12. The large hydrogen volume that can be produced at Marina location on solar intensity at 10 am until $12 \mathrm{pm}$ produces 3,925 to $4,200 \mathrm{ml}$. Whereas at Tembalang location it also produces quite large amount of hydrogen from solar intensity from 10 am until 12 pm can produce 4,930 to $5,752 \mathrm{ml}$.

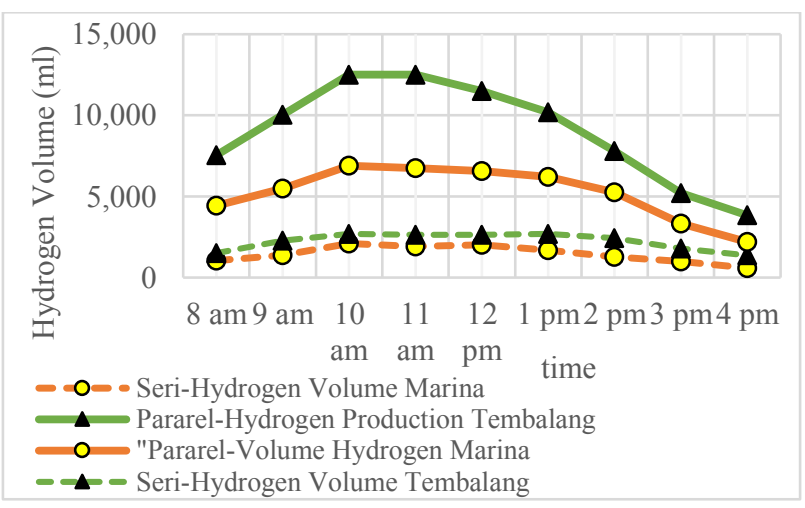

Fig. 13. Curve of Comparisson Hydrogen Volume

Figure 13 shows that volume hydrogen that can produced by single and parallel panel photovoltaic output current based on intensity solar radiation on Marina and Tembalang location. Solar Intensity received by fotovoltaic panels and then converted to current into the battery is proportional to the value volume hydrogen that can be produced. Higher solar intensity will provide 
greater hydrogen volume value. Locations in Marina, both single and parallel panels, have considerable intensity at 10 am until $12 \mathrm{pm}$ so that the energy and hydrogen production produced are quite large at that time. While in Tembalang has a large solar intensity at 10 am until $1 \mathrm{pm}$ for single panel and 10 am until $12 \mathrm{pm}$ for a parallel panel. The peak radiation intensity average starts at 10 am until $1 \mathrm{pm}$ [16]. Hydrogen produced at Marina location for a single panel is and for parallel panels are 2,099.93 and $4,199.86 \mathrm{ml}$. Whereas Tembalang location, using a single panel it can produce hydrogen about 2693.39 liters and for parallel is $5751.98 \mathrm{ml}$.

As previously stated, flowrate and the volume of hydrogen that can be produced are calculated using the ideal hydrogen volume equation assumed that electrolysis in STP conditions (298.15 K and $1 \mathrm{~atm})$, on steady-state process and hydrogen produced is the ideal gas. However, we have tried to use this ideal hydrogen volume formula to calculate from the results of alkaline water electrolysis experiments using solar energy as an energy source by Gustavo, Vieira and Damasceno, 2018. Result is shown in Table 5. The experiment used 5 mol / liter $\mathrm{NAOH}$ concentration, the electrode used was SS 304, operating temperature $27^{\circ} \mathrm{C} \pm 1.4$. The energy source comes from polycrystalline photovoltaic and a 4 hour trial time (10 am to $2 \mathrm{pm}$ ) every day for three days. The current obtained during the three days of the experiment is calculated using the formula for the ideal hydrogen gas volume. The calculation results are compared with the volume of hydrogen produced during the experiment shown in table 5. The current in amperes, $V_{1}$ is the ideal hydrogen gas volume (in $\mathrm{ml}$ ) and $\mathrm{V}_{2}$ is the volume of hydrogen produced during the experiment (in $\mathrm{ml}$ ). The results in table 5 show the volume of hydrogen produced in the experiment is still within the ideal hydrogen volume range.

Table 5. Comparison of Hydrogen Volume

\begin{tabular}{|c|c|c|c|}
\hline & Current $(\mathrm{A})$ & $\mathrm{V}_{1}(\mathrm{ml})$ & $\mathrm{V}_{2}(\mathrm{ml})$ \\
\hline Day 1 & $0.89 \pm 0.38$ & $1,625.16 \pm 693,89$ & 1,822 \\
\hline Day2 & $0.82 \pm 0.29$ & $1,497.34 \pm 529,55$ & 1,653 \\
\hline Day 3 & $0.98 \pm 0.07$ & $1,789.5 \pm 127,83$ & 1,996 \\
\hline
\end{tabular}

It can be concluded that the ideal hydrogen volume equation can be used to calculate the predicted volume of hydrogen that will be produced in a water electrolysis process. The results of the hydrogen volume during the experiment cannot be maximized due to several factors such as the concentration of electrolyte solution [13]. temperature [12], solar radiation, voltage stability and electrode composition.

The current and volume of hydrogen that can be produced from the potential of solar intensity at the Marina location is different from the location of Tembalang. Factors that influence hydrogen production are solar radiation [3]. Variations in irradiation affect the current given by the module. The higher solar radiation increases the current produced by the PV module. So that the energy produced by cell electrolysis and hydrogen production increases [15]. Power of the solar module affected by meteorological conditions that are the solar intensity [17]. The reduction in solar radiation directly decreases the system's electricity flow and gas production.

The intensity of the sun is influenced by altitude conditions. Marina location has a lower intensity of solar radiation compared to the Tembalang location so that it affects the result of hydrogen production which becomes lower than Tembalang, both for single and parallel panels. Marina's location is in the sub-district of North Semarang, which in Figure 5 shown in a lighter grey with a moderate value solar radiation. While Tembalang is at the location of the translucent shown on darker grey part in Figure 5. The darker grey part shows large solar radiation. This is due to the differences in altitude in the location. The altitude at Tembalang is 125 masl [18] and the Marina location altitude approximately 1 masl which is quite close to the beach. The higher a location, the higher the acceptable solar radiation, with every increase of $1000 \mathrm{~m}$, the global irradiation increases by approximately $8 \% \pm$ $2 \%$. [19]. This increase is mainly due to a pronounced increase of direct irradiance, whereas for altitudes below about $3,000 \mathrm{~m}$ the diffuse irradiance is more or less constant [20]. Figure 5 shown that The city of Semarang has the potential of large solar radiation in several subdistricts, namely Tugu, Tembalang and the western and eastern Ungaran border.

The output current from a parallel panel photovoltaic that is consisting of 2 single panels has a higher value than a photovoltaic single panel. That is comparable with solar intensity be received for both. This causes the production of hydrogen which can be produced by parallel panels larger than a single panel. Even from the calculation results, it produces a greater value of approximately 2 times. This shows that monocrystalline solar is effective for both single panel and parallel. It would be more effective if using more than one panel.

\section{Conclusion}

Hydrogen is an environmentally friendly energy source that will be developed by electrolysis and utilizing solar radiation as a source of electrical energy using single and parallel monocrystalline solar panels. Solar intensity data obtained from two locations in Semarang use single and parallel PV, namely at the Marina with altitude approximately 1 masl and Tembalang with altitude 125 masl, for 9 hours starting at $8 \mathrm{am}-4 \mathrm{pm}$. Then calculated flow rate dan volume of hydrogen can be produced used volume hydrogen ideal equation. The volume of hydrogen can be produced by 2 locations reaches a peak from 10 am to $1 \mathrm{pm}$. Radiation intensity potential at Tembalang location on a single panel and parallel panel both can be produced hydrogen with volume is $2,693.39 \mathrm{ml}$ and $5,751.98 \mathrm{ml}$. Whereas volume of hydrogen can be produced based on potential intensity radiation at the marina location is $2,099.93 \mathrm{ml}$ for single panel dan $4,199.86 \mathrm{ml}$ for parallel panel. The altitude affects the volume of hydrogen that can be produced. The higher altitude of the location that is the higher volume of hydrogen is produced. Monocrystalline solar panels arranged parallel produce greater solar intensity and 
energy than a single panel so that they can produce larger hydrogen with values reaching 2 times from a single panel.

\section{References}

1. K. Handayani, Y. Krozer, and T. Filatova, Tradeoffs between electrification and climate change mitigation: An analysis of the Java-Bali power system in Indonesia, Applied Energy, 208, pp. 1020-1037, (2017)

2. J. Chi and H. Yu, Water electrolysis based on renewable energy for hydrogen production, 39, 3: 390-394, (2018)

3. L. Gustavo, M. Vieira, and R. Damasceno, Science Direct Hydrogen production by a lowcost electrolyzer developed through the combination of alkaline water electrolysis and solar energy use, 3, 0-10 (2018)

4. F. Suleman, I. Dincer, and M. Agelin-Chaab, Environmental impact assessment and comparison of some hydrogen production options, Int. J. Hydrogen Energy, 40, 21: 69766987, Jun. (2015)

5. M. M. Mench, Fuel Cell Engines (2008)

6. K. Zeng and D. Zhang, Recent progress in alkaline water electrolysis for hydrogen production and applications, Prog. Energy Combust. Sci., 36, 3: 307-326 (2010)

7. S. Sulistyo, S. Prathama, J. D. Setiawan, and D. F. Fitriyana, Charging Quality of 100 Amperhours Battery Using a Silicon Photovoltaic at Different Altitude in Semarang Region, Proceeding - 2018 5th Int. Conf. Electr. Veh. Technol. ICEVT 2018, 1: 100-102 (2019)

8. M. R. Patel, Wind and Solar Power Systems design, Analysis, and Operation. (2006)

9. A. SACE and A, Technical Application Papers No.10 Photovoltaic plants, 10 (2010)

10. A. E. Johnson and E. C. Williams, Fuel cell efficiency, p. 278, (2012)

11. R. et. a. O'hayre, Fuel Cell Fundamentals, Third edit. .

12. M. Kaddami and M. Mikou, Science Direct Effect of operating parameters on hydrogen production by electrolysis of water, Int. J. Hydrogen Energy, 42, 40:. 25550-25557 (2017)

13. M. H. Sellami and K. Loudiyi, Electrolytes behavior during hydrogen production by solar energy, Renew. Sustain. Energy Rev., 70, no. July 2016, pp. 1331-1335 (2017)

14. F. J. W. Osseweijer, L. B. P. van den Hurk, E. J. H. M. Teunissen, and W. G. J. H. M. van Sark, $A$ comparative review of building integrated photovoltaics ecosystems in selected European countries, Renew. Sustain. Energy Rev., 90, no. April, pp. 1027-1040, (2018)

15. M. D. Cabezas, J. I. Franco, and H. J. Fasoli, Optimization of self-regulated hydrogen production from photovoltaic energy, Int. J. Hydrogen Energy, no. xxxx, (2018).
16. G. L. Morrison and Sudjito, Solar radiation data for indonesia, Sol. Energy, 49, 1: 65-76 (1992)

17. E. Roumpakias and A. Stamatelos, Comparative performance analysis of grid-connected photovoltaic system by use of existing performance models, Energy Convers. Manag., 150, no. August, pp. 14-25, (2017)

18. "GEOGRAFI DAN IKLIM Kota Semarang Dalam Angka 2018 11,” p. 2018, (2018)

19. M. Blumthaler, W. Ambach, and R. Ellinger, Increase in solar UV radiation with altitude, J. Photochem. Photobiol. B Biol., 39, 2: 130-134 (1997)

20. C. Lütz, Plants in Alpine regions: Cell physiology of adaption and survival strategies, Plants Alp. Reg. Cell Physiol. Adapt. Surviv. Strateg., pp. 1202, (2013) 